\title{
Subjetividade e produção de singularidades na formação docente
}

PEREIRA, Marcos Villela. Estética da professoralidade: um estudo crítico sobre a formação do professor. 1. ed. Santa Maria: EdUFSM, 2013. 248p.

Elenilda Alves Brandão

Universidade Estadual do Sudoeste da Bahia

Ederson Luís Silveira

Universidade Federal de Santa Catarina

Sobre a "Estética da professoralidade: um estudo crítico sobre a formação do professor" (PEREIRA, 2013 ) pode-se dizer que é o quarto livro do autor que atua na área de estudos da educação englobando a formação de professores, arte e educação, políticas e práticas educacionais. Marcos Villela Pereira é formado em Filosofia e concluiu o doutorado em Educação pela PUC/SP em

244 1996. Atualmente, é Professor Titular da Pontifícia Universidade Católica do Rio Grande do Sul dos cursos de Graduação e Pós-Graduação em Educação da Universidade. A obra desenvolvida em cinco capítulos que podem ser lidos em sequência ou aleatoriamente, ao gosto do leitor de acordo com suas zonas de interesse, integram os seguintes subtópicos: "Problematização", "Demarcação", "Caminhos da Microestética", "Exploração da Metáfora como Estratégia Crítica" e o último com o mesmo título do livro.

No primeiro capítulo, o autor situa o leitor em relação ao conceito de professoralidade, que, segundo ele, se explica como uma diferença que o sujeito experimenta na produção de si, instigando à reflexão acerca da prática docente de cada um. Utilizando-se de relatos autobiográficos, narra sua trajetória pessoal e profissional ressaltando experiências que produziram marcas, identificações e (des)configurações pessoas identitárias no terreno de contínua movência que é o terreno da formação docente. Autores, como Foucault, Deleuze, Guattari, Dreyfus, Rolnik, dialogam no presente texto em direção à demarcação teórica sobre a subjetividade que produz no sujeito (individual, coletivo) um processo de atualização de forças/fluxos em formação singular. No segundo capítulo, com base nas experiências do autor, são apresentados ainda para que estejam 
mobilizados caminhos que revelam a indissociabilidade com a formação da subjetividade observando como se produz o sujeito professor dentro das práticas. Utiliza-se a provocação para o cuidado de si através da busca de um olhar cuidadoso e investigativo sobre si e os gestos de cada um nos terrenos da docência para descobrir na memória, especialmente nas cartografias, momentos de investidura profissional quando o professor para de "fugir" e enfrenta a si mesmo e escolhe-se professor. Neste sentido, pode o leitor se deparar com diferentes dimensões da memória observando os abalos/caos que provocaram edificações e demolições nas práticas professorais que apontam para o gênesis de um contínuo devir na produção das subjetividades.

No terceiro capítulo, o autor transita pelos caminhos da microestética lcomo caminho de produção de singularidades e diferenças objetivando discussões acerca das construções e desconstruções sobre o conceito de estética e sua consequência no meio social) fazendo "desfilar" as ideias de Deleuze sobre dois tipos de aulas: aulas palestras e aulas pesquisas. Pode-se destacar, no primeiro tipo de aula, a historicidade das repetições de conteúdo e técnicas escolares e, no segundo tipo, o convite à instigação, à inquietação, ao desbravar mundo que deveria estar presente na escola, o filosofar. Propõe que se coloque "abaixo" a função repetidora da memória e inaugure a sua função expansiva, para que sejam possibilitados movimentos em torno do fluxo permanente de transformação, subjetividade, devir. Nesse ponto, o autor debruça-se sobre o pensamento dos autores Nóvoa, Ferrarotti e Peneau, Simondon, Josso, Foucault e Rolnik para construir uma reflexão sobre o estudo das histórias de vida especialmente para associar ao processo de formação do professor, destacando as experiências "charneiras" que produziram marcas no sujeito capazes de gerar um desmanchamento e edificação de mundos.

avanço para o campo da microestética vai possibilitando o clareamento das discussões no campo da subjetividade apresentados como estado de forças vitais, retornando à memória, recortes da história como crônica da vida, partindo para a compreensão dos avanços contínuos em consonância com o pensamento de Simondon, cuja expressão identifica o ser sempre prenhe de transformação, por isso, metaestável. Daí, surge a denúncia a partir de Lefreve, que verifica a estrutura social que impõe o crivo dos quadrados, como abortiva e reguladora das subjetividades, a fim de perpetuar o poder. $\bigcirc$ ator aponta então para o pensamento de Deleuze e Guattari como uma proposição de forças e resistências em que a atualização e as diferenças são produzidas capazes de 
emergir como território existencial de alteridade e subjetividade. Neste contexto, a (constituição da) subjetividade é tomada aqui como processualidade; microentética; máquina autopoiética.

No capítulo quatro, utilizam-se exemplos de metáforas para melhor explicitar que a produção das subjetividades remete à indissociabilidade entre o individual e o coletivo, já que as metáforas precisam de reconhecimento coletivo para ter existência enquanto artefato cultural reproduzivel (e reproduzido) e de identificação individual para serem continuamente ressignificadas nas experiências de "professoralidade". Dessa forma, o autor busca caracterizar o uso da metáfora como estratégia crítica para a possibilidade do seu uso como pressuposto de ressonância, migração conceitual ou contaminação, movimentos que apontam para considerações acerca da história de vidas e identidades em movimento e à memória dos professores sujeitos de sua investigação, com vistas a perceber a "estética da professoralidade". Nesse momento, entram em cena algumas discussões propostas por Aristóteles e Edgar Morin.

No quinto e último capítulo, também o mais longo, a estética da professoralidade deixa-se contemplar por inteiro, logo o leitor percebe que as tramas que foram discutidas até que aqui se chegasse, foram essenciais para o entendimento 246 de toda a obra. $\bigcirc$ autor revela, seus preceitos, entraves, angústias, escolhas, diferenças. Numa narrativa poética, produz, com sensibilidade e leveza, uma escrita sobre si num alto grau de plenitude enquanto ser que se estabelece no caos da existência. Como um jogo de amarelinha, vai explorando a própria estética da professoralidade em nuances de subjetivação enquanto sujeito cidadão do mundo. $\bigcirc$ enfoque na percepção da singularidade produzida a partir do autoconhecimento; da memória projetiva e da produção da diferença é o que permeia boa parte deste capítulo final.

Por tudo o que foi mencionado até aqui, esta obra, através de amplas remissões bibliográficas torna-se ferramenta para um viés reflexivo acerca da reflexão e produção de si. As duzentas e trinta e seis páginas traduzem uma proposta consistente de se vivenciar a teia incessante da produção das subjetividades enquanto movimento marcado pelo contínuo devir, direcionadas a quem quiser refletir sobre os modos de constituição de si em relação à sua formação e ao comprometimento e papel responsável em relação à alteridade subjacente aos contextos educacionais em que estiver (se) inseri(n)do. 
Profa. Especialista Elenilda Alves Brandão

Universidade Estadual do Sudoeste da Bahia Pós-graduanda do Curso de Especialização em Filosofia Contemporânea | UESB | Bahia Profa. de Filosofia da Rede Estadual de Ensino da Bahia Professora de Filosofia do Ensino Fundamental II da Rede Municipal de |birapitanga | Bahia E-mail | elenilda.farias@yahoo.com.br

Mestrando Ederson Luís Silveira Universidade Federal de Santa Catarina | UFSC Bolsista CAPES Membro do FORMATE | Grupo de Estudos em Territorialidades da Infância e Formação Docente da Universidade Estadual do Sudoeste da Bahia E-mail | ediliteratus@gmail.com

Recebo 25 maio 2014 Aceito 30 jul. 2014 